TARNOWSKIE STUDIA TEOLOGICZNE 37 (2018) NR 1-2, S. 167-191

http://dx.doi.org/10.15633/tst.3257

ks. Andrzej Michalik ${ }^{1}$

UNIWERSYTET PAPIESKI JANA PAWŁA II W KRAKOWIE

\title{
Charakterystyczne cechy egzegezy Pisma Świętego św. Tomasza z Akwinu
}

Święty Tomasz z Akwinu był nie tylko znakomitym filozofem i teologiem. Akwinata był także egzegetą. Komentarz wybranych ksiąg Pisma Świętego był codziennym zajęciem magistra średniowiecznego uniwersytetu². Temu zadaniu poświęcał on codziennie pierwsze godziny swej pracy dydaktycznej. Liczne komentarze do ksiąg Pisma Świętego oraz inne dzieła Doktora Anielskiego pozwalają wyodrębnić charakterystyczne cechy jego egzegezy. Spróbujemy je przybliżyć w niniejszym szkicu.

Święty Tomasz był świadomy tego, że wyjaśnianie Biblii nie jest łatwym zadaniem, ponieważ głównym autorem Pisma Świętego jest Duch Święty. Słowa Pisma zawierają więc o wiele więcej niż to, co są zdolni pojąć ci, którzy je wyjaśniają ${ }^{3}$. Konieczna jest zatem pomoc Boża ${ }^{4}$. Chodzi bowiem o prawdę, która wymaga najwyższej uwagi ${ }^{5}$. Niełatwo jest zrozumieć myśl

1 Ks. Andrzej Michalik, dr hab. teologii, wykładowca teologii fundamentalnej i religiologii na Wydziale Teologicznym Sekcja w Tarnowie UPJP II w Krakowie, rektor Wyższego Seminarium Duchownego w Tarnowie.

2 Por. J. A. Weisheipl, Tomasz z Akwinu. Życie, myśl i dzieło, tłum. C. Wesołowski, Poznań 1985, s. 149.

3 "Ad quintum dicendum, quod auctor principalis sacrae Scripturae est Spiritus sanctus, qui in uno verbo sacrae Scripturae intellexit multo plura quam expositores sacrae Scripturae exponantur vel discernantur" (Św. Tomasz z Akwinu, Quaestiones Quodlibetales 7, q. 6, a. 1, ad 5, Romae 1949).

4 „Intendimus enim compendiose, secundum nostram possibilitatem, de divino auxilio fiduciam habentes, librum istum, qui intitulatur beati Job, secundum litteralem sensum exponere" (Św. Tomasz z Akwinu, Expositio in Librum Sancti Job. Prologus s. Thomae, t. 18, Parisiis 1876, s. 2).

5 „Duo sunt vitanda; quorum unum est ne in hac quaestione aliquid falsum asseratur, praecipue quod veritati fidei contradicat; aliud est, ne quidquid verum aliquis esse crediderit, statim velit asserere, hoc ad veritatem fidei pertinere" (Św. Tomasz z Akwinu, Quaestio disputata De Potentia, q. 4, a. 1, w: Quaestiones disputatae, t. 2, Taurini-Romae 1965, s. 7-276). 
drugiego. Jeszcze trudniej, gdy szuka się prawdy, która pochodzi od Autora boskiego i autora ludzkiego Pisma Świętego ${ }^{6}$ i nie zawsze możliwe jest osiągnięcie pewnej interpretacji tekstu. Według św. Tomasza prawda tekstu zależy od intencji autora ${ }^{7}$. A więc zadaniem komentatora jest poszukiwanie w konkretnym wyrażeniu intencji autora. Średniowieczna egzegeza odnalazła tę hermeneutyczną zasadę sformułowaną przez św. Augustyna $^{8}$ i św. Tomasz wiernie ją stosował'

6 Por. M. Arias Reyero, Thomas von Aquin als Exeget, Einsiedeln 1971, s. 215; M.-D. Chenu, Introduzione allo studio di san Tommaso d'Aquino, Firenze 1965, s. 166.

7 „Veritas non attenditur secundum sensum quem verba faciunt, sed secundum quod loquens exprimere intendit" (Św. Tomasz z Akwinu, Super Primam Epistolam ad Corinthios lectura, c. 11, 1. 1, nr 585, w: Super Epistolas Pauli lectura, Taurini-Romae 1953). Por. także: M. Arias Reyero, Historia y teología. La interpretación de la Escritura en santo Tomás, „Salmaticensis” 22 (1975), s. 516nn.

8 „Et cum divinos Libros legimus in tanta multitudine verorum intellectuum, qui de paucis verbis eruuntur, et sanitate catholicae fidei muniuntur, id potissimum deligamus, quod certum apparuerit eum sensisse quem legimus; si autem hoc latet, id certe quod concordantia Scripturae non impedit, et cum sana fide concordat; si autem et Scriprturae circumstantia pertractari ac discuti non potest, saltem id solum quod fides sana praescribit. Aliud est enim quid potissimum scriptor senserit non dignoscere, aliud autem a regula pietatis errare. Si utrumque videtur, perfecte se habet fructus legentis: si vero utrumque vitari non potest, etiam si voluntas scriptoris incerta sit sanae fidei congruam non inutile est eruisse sententiam" (Św. Augustyn, De Genesi ad litteram, lib. 1, cap. 21 [Nuova Biblioteca Agostiniana 9/2], Roma 1986, s. 56-58; PL 34, 262). Por. także: C. Spicq, Exégèse médiévale, w: Dictionnaire de la Bible. Supplement, t. 4, 1949, kol. 625 .

9 „Ut profundius intentionem scrutemur” (Św. Tomasz z Akwinu, Quaestio disputata De Spiritualibus Creaturis, a. 10, ad 8, w: Quaestiones disputatae, t. 2, Taurini-Romae 1954, s. 367-415); „Et hoc magis facit ad intentionem Apostoli” (Św. Tomasz z Akwinu, Super Primam Epistolam ad Timotheum, c. 2, 1. 1, nr 62, w: Super Epistolas Pauli lectura, dz. cyt.); „Sed licet haec lectura sustineri possit, non tamen est secundum intentionem Apostoli" (Św. Tomasz z Akwinu, Super Epistolam ad Galatas lectura, c. 4, 1. 4, nr 223, w: Super Epistolas Pauli lectura, dz. cyt.); „Haec responsio non videtur esse omnino secundum intentionem Apostoli” (Św. Tomasz z Akwinu, Super Epistolam ad Romanos lectura, c. 3, 1. 2, nr 273, w: Super Epistolas Pauli lectura, dz. cyt.); „Ponuntur autem et alii sensus auctoritatis [...] qui non ita pertinent ad intentionem Apostoli” (Św. Tomasz z Akwinu, Super Epistolam ad Romanos lectura, c. 3, 1. 1, nr 259m, w: Super Epistolas Pauli lectura, dz. cyt.); „Et haec expositio est litteralis, et secundum intentionem Apostoli" (Św. Tomasz z Akwinu, Super Epistolam ad Romanos lectura, c. 4, 1. 1, $\mathrm{nr}$ 331). Na ten temat zob. także: I. Biffi, La Teologia e un Teologo: San Tommaso d'Aquino, Casale Monferrato 1984, s. 65n; O. Lottin, Comment interpréter et utiliser saint Thomas d'Aquin, „Ephemerides Theologicae Lovanienses” 36 (1960), s. 59; S. H. Siedl, Thomas von Aquin und die moderne Exegese, „Zeitschrift für Katholische Theologie” 93 (1971), s. 4on; C. Spicq, Saint Thomas d'Aquin exégète, w: Dictionnaire de la théologie catholique, sous la direction de A. Va- 
Poszukiwanie prawdy, a zatem intencji autora, streszcza bardziej szczegółowy wysiłek w egzegezie jakiegoś tekstu lub księgi, które - ze swej strony - dostarczają impulsów, aby opisać jakąś egzegezę. Charakterystyczne cechy egzegezy św. Tomasza z Akwinu można przedstawić w następujących punktach: egzegeza według dwóch reguł fundamentalnych - analogii wiary katolickiej i analogii wiary biblijnej, egzegeza scholastyczna, egzegeza patrystyczna i egzegeza teologiczna.

\section{Egzegeza według dwóch reguł fundamentalnych - analogia wiary katolickiej i analogia wiary biblijnej}

Ponieważ Pismo Święte jest księgą sui generis, „nakłada na tego, kto ją czyta, szczegółowe wskazania dla jej zrozumienia"ı. Święty Tomasz uważa, że Pisma powinny być wyjaśniane w tym samym Duchu, w którym zostały napisane ${ }^{11}$. Szczególnymi zasadami, opartymi na prawdzie, że autorem Pisma Świętego jest Duch Święty ${ }^{12}$, są przede wszystkim dwie reguły: reguła analogii wiary katolickiej i analogii wiary biblijnej ${ }^{13}$. Obydwie mają korzenie patrystyczne ${ }^{14}$.

cant, E. Mangenot, É. Amann, t. 15, Paris 1946, kol. 730; C. M. J. Vansteenkiste, Il metodo di san Tommaso, w: Le ragioni del tomismo. Dopo il centenario dellenciclica "Aeterni Patris", a cura di A. Livi, C. Fabro, F. Ocariz, C. M. J. Vansteenkiste, Milano 1979, s. 161-196n.

${ }_{10}$ M.-D. Chenu, La teologia come scienza nel XIII secolo, Milano 1985, s. 31.

${ }^{11}$ „Ab eodem Spiritu Scripturae sunt expositae et editae” (Ŝw. Tomasz z Akwinu, Quaestiones Quodlibetales 12, q. 17, a. 1).

${ }_{12}$ „Auctor principalis sacrae Scripturae est Spiritus sanctus” (Św. Tomasz z Akwinu, Quaestiones Quodlibetales 7, q. 6, a. 1, ad 5).

${ }^{13}$ „In rebus enim dubiis non est de facili praestandus assensus; quinimmo ut Augustinus dicit in lib. III de Doctrina Cristiana, «consulere debet quis regulam fidei, quam de Scripturarum planioribus locis et de Ecclesiae auctoritate percipit»" (Św. Tomasz z Akwinu, Quaestiones Quodlibetales 3, q. 4, a. 2).

${ }^{14} \mathrm{O}$ ich pochodzeniu od św. Augustyna por. C. Spicq, Exégèse médiévale, kol. 62on; C. Spicq, Saint Thomas d'Aquin exégète, kol. $727 \mathrm{nn}$. Te dwie reguły są syntetyzowane dzisiaj przez Maximina Ariasa Reyera w jednej formule: „Dzisiaj egzegeza, która nazywa się chrześcijańską, ma za podstawę następujące elementy: boskie pochodzenie Objawienia, ludzki sposób jego przekazu i związek obydwu w Chrystusie [...]. Kościół nauczył się widzieć Objawienie i jego znaczenie dla niego samego w świetle wiary w Chrystusa" (M. Arias Reyero, Thomas von Aquin als Exeget, s. 252). 


\section{Analogia wiary katolickiej}

Kościół „uczy się” swej wiary z Pisma Świętego i Tradycji ${ }^{15}$. A więc to, w co Kościół wierzy, nie może być sprzeczne z Biblią. I odwrotnie, interpretacja Pisma Świętego nie może sprzeciwiać się wierze Kościoła ${ }^{16}$. Interpretacja przeciwna wierze Kościoła byłaby pójściem za prywatną nauką, a nie za nauką przekazaną przez Boga $^{17}$. Odwołanie się do analogii wiary katolickiej jest konieczne w wyjaśnianiu tekstów bardziej niejasnych ${ }^{18}$.

Dla przykładu, w komentarzu wersetu z Ewangelii według św. Jana „Na początku było Słowo, a Słowo było u Boga” (J 1, 1), Akwinata odrzuca twierdzenie arian, którzy utrzymywali, że Syn jest zrodzony przez Ojca aktem woli, a więc jest mniejszy niż Ojciec ${ }^{19}$. W szerszym kontekście pogłębionego wyjaśnienia ${ }^{20}$ Doktor Powszechny - po ukazaniu niemożliwości porównania zrodzenia Syna Bożego do zrodzenia ludzkiego - stwierdza, że również zrodzenie przez akt woli nie jest możliwe, ponieważ Ojciec rodzi Syna z natury. Swoje wyjaśnienie ilustruje przez dwie analogie (ognia i blasku oraz syna), i potwierdza przez orzeczenie Soboru Efeskiego, a więc przez analogię wiary Kościoła ${ }^{21}$. Można

15 „Omnibus articulis fidei inhaeret fides propter unum medium, scilicet propter veritatem primam propositam nobis in Scripturis secundum doctrinam Ecclesiae intellectis sane" (Św. Tomasz z Akwinu, Summa Theologiae, 2-2, q. 5, a. 3, ad 2 [La Somma Teologica, edizione italiano-latina, Città di Castello 1950-1975]).

${ }^{16}$ Por. M. Arias Reyero, Thomas von Aquin als Exeget, s. 254-259.

${ }^{17}$ „De ratione haeresis est, quod aliquis privatam disciplinam sequatur, quasi per electionem propriam: non autem disciplinam publicam, quae divinitus traditur" (Św. Tomasz z Akwinu, Super Primam Epistolam ad Corinthios lectura, c. 9, 1. 4, nr 627).

${ }_{18}$ Por. J. Correia Margarido, A analogia da Fé na exegese de S. Tomás, „Theologica” 13 (1978), s. $328-350$.

19 „Similiter non potest dici quod Pater sua voluntate initium durationis Filio suo praestiterit; quia Deus Pater non generat Filium voluntate, ut Ariani dixerunt, sed naturaliter: Deus enim Pater seipsum intelligendo, Verbum concepit, et ideo non ante fuit Deus Pater quam Filius" (Św. Tomasz z Akwinu, Super Evangelium Ioannis lectura, c. 1, 1. 1, nr 41, Taurini-Romae 1952).

${ }^{20}$ W którym Doktor Anielski odwołuje się do analizy naturalnego zrodzenia, następnie do metafizycznej zasady aktu i potencji.

${ }^{21}$ „Et hoc est quod dicitur in libro Ephesini Concilii, coexistere semper Patri Filium: splendor enim denunciat impassibilitatem, nativitas ostendit Verbum, consubstantialitatem vero Filii nomen insinuat" (Św. Tomasz z Akwinu, Super Evangelium Ioannis lectura, c. 1, 1. 1, nr 41). W nocie zamieszczonej w edycji włoskiej wspomnianego Komentarza czytamy, że „św. Tomasz cytuje w tym miejscu prawie dosłownie Akta Soboru Efeskiego" (Św. Tomasz z Akwinu, Commento al Vangelo di San Giovanni, t. 1, Roma 1990, s. 60). 
zauważyć, że w argumentacji Akwinaty odwołanie się do wiary Kościoła wyrażonej na soborze w Efezie nie ma charakteru determinującego. Jednak ta wiara prowadzi św. Tomasza przez cały fragment, który komentuje.

Zupełnie inny jest charakter odwołania się do reguły wiary katolickiej w innym fragmencie tego samego komentarza, w którym Doktor Anielski wyjaśnia zdanie Jezusa: „Ten bowiem, kogo Bóg posłał, mówi słowa Boże: a z niezmierzonej obfitości udziela [mu] Ducha" (J 3, 34). To odwołanie się spotykamy w kontekście niemal quaestio wprowadzonej przez Akwinatę do komentarza biblijnego (jako sed contra). Doktor Powszechny stwierdza, że Duch Święty jest dany Chrystusowi „bez miary”, natomiast innym, na przykład prorokom „według pewnej miary”22. W tym miejscu św. Tomasz stawia kwestię, w jaki sposób Duch Święty może być dany według miary, jeśli On sam jest niezmierzony. Przywołuje świadectwo symbolu św. Atanazego, w którym stwierdza się: „Niezmierzony Ojciec, niezmierzony Syn, niezmierzony Duch Święty"23.

Komentując poczęcie Jezusa Chrystusa w łonie Maryi (por. Mt 1, 18), Akwinata wyjaśnia - wykorzystując analogię między słowem ludzkim i Słowem Bożym - zrodzenie Słowa. W tym kontekście twierdzenia Soboru Efeskiego zostają dodane jako tertia ratio ${ }^{24}$.

${ }^{22}$ „Denuntiandi autem facultas subest Christo maxima, quia non ad mensuram recipit spiritum Non enim ad mensuram dat Deus spiritum. Posses enim dicere, quod licet miserit eum Deus, tamen non omnia a Deo loquitur, sed aliqua: nam et Prophetae aliquando quidem locuti sunt ex spiritu suo, aliquando vero ex spiritu Dei [...]. Sed hoc ostendit Baptista locum non habere in Christo; quia Prophetae quidem accipiunt spiritum Dei mensurate, scilicet quantum ad aliquid non quantum ad omnia, et ideo non quantum ad omnia verba Dei loquuntur; Christus autem, qui absque mensura et quantum ad omnia spiritum recepit, ideo quantum ad omnia verba Dei loquitur" (Św. Tomasz z Akwinu, Super Evangelium Ioannis lectura, c. 3, 1. 6, nr 541).

${ }^{23}$ „Sed quomodo Spiritus sanctus datur ad mensuram, cum sit immensus, secundum Athanasium in suo symbolo: "Immensus Pater, immensus Filius, immensus Spiritus sanctus»?" (Św. Tomasz z Akwinu, Super Evangelium Ioannis lectura, c. 3, 1. 6, nr 542). W rozwiązaniu tej kwestii - która nas w tym miejscu nie bardzo interesuje - Akwinata rozróżnia udzielanie się Ducha przez istotę i przez moc, według których Duch Święty jest nieskończony, ale także przez swe dary, które udzielane są zgodnie z miarą (por. tamże).

${ }^{24}$ „Tertia ratio assignatur in gestis Nicaeni concilii, et est, quod in nobis est duplex verbum: verbum cordis et verbum vocis" (Św. Tomasz z Akwinu, Super Evangelium Matthaei lectura, c. 1, nr 112, w: Tommaso D’Aqcuino, Commento al Vangelo Secondo Matteo, capitoli 1-14, intorduzione e traduzione R. Coggi, Bologna 2018, s. 108). 


\section{Analogia wiary biblijnej}

Godny uwagi jest wysiłek św. Tomasza, by „Biblię wyjaśniać Biblią”25. Ta cecha jego egzegezy opiera się na przekonaniu o organicznej jedności Pisma Świętego i jego wewnętrznej harmonii. W Piśmie Świętym nie ma tekstów sprzecznych i dlatego próbuje się wyjaśniać te, które są bardziej niejasne, tymi, które są bardziej jasne, a więc czytać każdy fragment w łączności z całym Pismem ${ }^{26}$.

Doktor Anielski w swych komentarzach do Pisma Świętego bardzo często odwołuje się do tekstów paralelnych; zestawia je, szukając w ten sposób lepszego zrozumienia komentowanego tekstu ${ }^{27}$. Analogia wiary biblijnej wyraża się u św. Tomasza poprzez lekturę Starego Testamentu w świetle Nowego, poprzez wyjaśnianie jednego fragmentu autora natchnionego w zestawieniu $\mathrm{z}$ innymi fragmentami tego samego autora, a wreszcie także przez porównanie tekstu jednego autora $\mathrm{z}$ tekstami innych autorów ${ }^{28}$.

Na przykład proroctwo Micheasza: „Wystąpi przewodnik przed nimi” (Mi 3, 13), jest wyjaśniane w świetle słów Jezusa: „I nikt nie wstąpił do nieba, oprócz Tego, który z nieba zstąpił - Syna Człowieczego" (J 3, 13). W komentarzu tego zdania Jezusa św. Tomasz odwołuje się także do innego nowotestamentalnego tekstu, tym razem do św. Pawła: „Ten, który zstąpił, jest i Tym, który wstąpił" (Ef 4, 10). Teksty Nowego Testamentu sprawiają, że tajemnicze zdanie Micheasza zyskuje jasność. Jezus jest Tym, który zstąpił z nieba, aby nam otworzyć drogę swoim wstąpieniem ${ }^{29}$. Ale także zdanie ze Starego Testamentu ze swej strony - czyni jaśniejszymi stwierdzenia Nowego.

${ }^{25}$ C. Spicq, Saint Thomas d'Aquin exégète, kol. 721. Według św. Tomasza z analogią biblijną mamy do czynienia wtedy, gdy można wykazać, że prawda jednego fragmentu Pisma Świętego nie jest w sprzeczności z prawdą innego fragmentu. „Analogia vero est, cum veritas unius Scripturae ostenditur veritati alterius non repugnare" (Św. Tomasz z Akwinu, Summa Theologiae, 1, q. 1, a. 10, ad 2).

${ }^{26}$ Por. G. Ferraro, Lo Spirito Santo nel Commento di san Tommaso d'Aquino ai capitoli XIVXVI del Quarto Vangelo, w: San Tommaso d'Aquino nel settimo centenario, w: San Tommaso d'Aquino nel suo settimo centenario, a cura di B. D'Amore, t. 4, Napoli 1976, s. 89n.

${ }^{27}$ Por. S. H. Siedl, Thomas von Aquin und die moderne Exegese, s. 32.

${ }_{28}$ Por. J. Correia Margarido, A analogia da Fé na exegese de S. Tomás, s. 313nn, 318nn, 322nn.

29 „Et statim incipit ostendere, cuius sit in caelum ascendere proprium: quia omnis qui de caelo descendit, secundum illud Eph. 4,10: Qui descendit ipse est et qui ascendit [...]. Unde hoc modo potest fieri ut aliquis per spiritum vadat ad locum quem carnales nesciunt, ascendendo in caelum, si hoc fiat per virtutem eius qui descendit de caelo: quia ad hoc descendit, 
„Gdybyście Mnie miłowali, rozradowalibyście się, że idę do Ojca, bo Ojciec większy jest ode Mnie" (J 14, 28). To tekst trudny i niejasny, na którym Ariusz oparł swój błąd. Ten błąd jest odrzucony, a następnie wyjaśnione jest to zdanie, przez słowa samego Pana. Aby wyjaśnić trudne wyrażenie „Ojciec większy jest ode Mnie”, św. Tomasz inspiruje się innym wyrażeniem tego samego zdania: „Idę do Ojca”. Ponieważ ze sposobu rozumienia wyrażenia „Idę do Ojca” musimy zrozumieć także wyrażenie „Ojciec większy jest ode Mnie”. Aby wyjaśnić wyrażenie „Idę do Ojca”, Akwinata odwołuje się do innego tekstu św. Jana: „Na początku było Słowo, a Słowo było u Boga" $(J 1,1)$. Syn więc nie idzie do Ojca i od Niego nie przychodzi, o ile jest Synem Bożym, który przebywa odwiecznie z Ojcem. Syn idzie do Ojca w swej ludzkiej naturze. Tym samym, gdy mówi „większy jest ode Mnie”, nie mówi jako Syn Boży, ale jako Syn Człowieczy ${ }^{30}$. W tym fragmencie warto zauważyć znaczenie innego tekstu św. Jana przywołanego przez św. Tomasza, aby wyjaśnić trudny fragment. To przykład analogii wiary biblijnej w obrębie tej samej Ewangelii.

Na koniec wypada przywołać przykład trzeciej formy użycia reguły analogii, którą wyjaśniamy, to jest tę, gdy Akwinata stara się wyjaśnić jakiś tekst jednego autora poprzez teksty innych autorów. „Nikt nie może przyjść do Mnie, jeżeli go nie pociągnie Ojciec, który Mnie posłał” (J 6, 44). Doktor Anielski pyta: Dlaczego mówi się tu, że Ojciec pociąga do Syna, podczas gdy wcześniej wiele razy mówiło się, że Syn pociąga do Ojca? Następnie przytacza dwa teksty (z Ewangelii Jana i Mateusza), które potwierdzają jego pytanie. Czytamy bowiem: „Nikt też nie zna Syna, tylko Ojciec, ani Ojca nikt nie zna, tylko Syn i ten, komu Syn zechce objawić” (Mt 11, 27); oraz „Objawiłem imię Twoje ludziom, których Mi dałeś ze świata” (J 17, 6). Chrystus, jak Bóg, prowadzi nas do Ojca. Te dwa teksy są jeszcze objaśnione przez trzeci tekst. Chrystus powiedział: „Ja jestem drogą" (J 14, 6). Na przytoczone wyżej pytanie św. Tomasz odpowiada w następujący sposób: O Chrystusie możemy mówić albo jako o człowieku,

ut ascendens, nobis viam aperiret; Mich. 2,13: Ascendit pandens iter ante eos" (Św. Tomasz z Akwinu, Super Evangelium Ioannis lectura, c. 3, 1. 2, nr 466).

${ }^{30}$ „Sed ex hoc Arius insultat dicens Patrem maiorem esse Filio. Cuius error ex ipsis verbis Domini excluditur. Nam ex intellectu eius, quomodo intelligitur Vado ad Patrem, ex eodem intelligitur Pater maior me est. Filius autem non vadit ad Patrem nec venit ad nos inquantum est Filius Dei, secundum quod cum Patre fuit ab aeterno; supra 1: In principio erat Verbum, et Verbum erat apud Deum. Sed dicitur ire ad Patrem, secundum humanam naturam. Sic ergo hoc quod dicitur Maior me est, non dicit inquantum Filius Dei, sed inquantum Filius hominis" (Św. Tomasz z Akwinu, Super Evangelium Ioannis lectura, c. 14, 1. 8, nr 1970). 
albo jako o Bogu. Jako człowiek, Chrystus jest drogą, a więc prowadzi do Ojca. Ojciec natomiast pociąga nas do Chrystusa jako człowieka, ponieważ udziela nam swej mocy, abyśmy wierzyli w Chrystusa. To twierdzenie ilustrowane jest przez słowa św. Pawła: „Łaską bowiem jesteście zbawieni przez wiarę. A to pochodzi nie od was, lecz jest darem Boga" (Ef 2, 8). Chrystus więc jako Słowo Boga i Ten, kto objawia Ojca, przyciąga do Ojca. W ten sposób Syn przyciąga do Ojca. Ojciec natomiast pociąga do Syna, o ile Go ukazuje ${ }^{31}$. Widać więc, jak teksty innych ksiąg przytoczone przez Akwinatę pomagają wyjaśnić tekst Jana.

Reguły analogii wiary katolickiej i analogii wiary biblijnej w jedności z zasadą prawdy Pisma Świętego ${ }^{32}$ stanowią fundament rozwiązywania antynomii biblijnych. Rzeczywiście, św. Tomasz wiele razy stawiał czoła „rozbieżnościom” między różnymi Ewangeliami ${ }^{33}$. Odnośnie do tego Settimo Cipriani stara się wydobyć z tekstów Doktora Anielskiego „pewne zasady”, które sugerowałby sam św. Tomasz. Pierwszą zasadą jest, że prawda „znajduje się nie w szczegółach, lecz w całościowym obrazie rzeczy, które hagiografowie starają się naprawdę przekazać jako orędzie zbawcze”34. Druga mówi, że „to nie treść opowiadana warunkuje hagiografa, lecz odwrotnie" ${ }^{35}$. Trzecią jest „pewien «konkordyzm»", to znaczy wysiłek odnalezienia zgodności między Ewangelistami ${ }^{36}$.

${ }^{31}$ „Secunda quaestio est: quia cum dicatur quod Filius trahit ad Patrem, Mt 11,27: Nemo novit Patrem nisi Filius, et cui voluerit Filius revelare; et infra 17,6: Pater, manifestavi nomen tuum hominibus quos dedisti mihi: quomodo hic dicitur, quod Pater trahit ad Filium? Sed dicendum quod ad hoc potest dupliciter responderi: nam de Christo possumus loqui aut secundum quod est homo aut secundum quod est Deus. Secundum autem quod homo, Christus est via; infra 14,6: Ego sum via: et secundum quod est Christus, ducit ad Patrem, sicut via ad terminum seu finem. Pater vero trahit ad Christum hominem inquantum dat nobis suam virtutem, ut credamus in Christum; Eph. 2,8: Gratia salvati estis, et hoc non ex vobis, Dei enim donum est. Inquantum est Christus, est Verbum Dei, et manifestativum Patris. Sic Filius trahit ad Patrem. Pater autem trahit ad Filium inquantum manifestat ipsum" (Św. Tomasz z Akwinu, Super Evangelium Ioannis lectura, c. 6, 1. 5, nr 936).

${ }^{32}$ „Hoc [...] tenedum est, quod quidquid in sacra Scriptura continetur, verum est” (Św. Tomasz z Akwinu, Quaestiones Quodlibetales 12, q. 17, a. 1).

${ }_{33}$ Por. S. H. Siedl, Thomas von Aquin und die moderne Exegese, s. 42; C. Spicq, Exégèse médiévale, kol. 625n; C. Spicq, Saint Thomas d’Aquin exégète, kol. 733-735.

${ }^{34}$ S. Cipriani, Riflessioni esegetiche su „Super S. Ioannis Evangelium lectura” di s. Tommaso, w: San Tommaso d'Aquino nel suo settimo centenario, s. 50.

${ }^{35}$ S. Cipriani, Riflessioni esegetiche su „Super S. Ioannis Evangelium lectura” di s. Tommaso, S. $50-52$.

${ }^{36}$ Por. S. Cipriani, Riflessioni esegetiche su „Super S. Ioannis Evangelium lectura” di s. Tommaso, s. 50-52. 
Te dwie reguły można zatem uważać za pierwszą cechę charakterystyczną egzegezy św. Tomasza. Dają one tej egzegezie pewność i obiektywnośćc ${ }^{37}$. Z tych dwóch reguł pierwsza jest mniej oczywista niż druga, ale nie mniej obecna. Co więcej, bez wątpienia znajduje się u podstaw każdego tekstu i każdej strony.

\section{Egzegeza scholastyczna}

Egzegeza scholastyczna $^{38}$ jest „egzegezą, w której obiektywna analiza tekstu przy pomocy odpowiednich metod, a nie duchowe zbudowanie słuchaczy, jest celem pracy szkoły"39. Do tej obiektywnej analizy prowadzą podziały, podpodziały i opozycje, aby uchwycić pełny sens tekstów zarówno w ich całości (dominująca idea księgi i jej główne idee), jak i w szczegółach, aż do pojedynczych wersetów lub nierzadko pojedynczych słów ${ }^{40}$. James A. Weisheipl wyjaśnia to w następujący sposób: „Podstawą całej metody scholastycznej był tekst. Urywek tekstu, święta stronica (sacra pagina), czytany był głośno w czasie zajęć szkolnych. Nie wszyscy bowiem studenci w połowie trzynastego wieku posiadali własne Biblie, a nawet jeśli je posiadali, to i tak odczytywano odpowiedni urywek dla odświeżenia pamięci. Po przeczytaniu tekstu mistrz dzielił go na części. Wprowadzenie podziału było sprawą najistotniejszą, ponieważ uważano, iż podział porządkuje całość i ułatwia zrozumienie. Następnie przeprowadzano dokładną analizę każdego wiersza i każdego poszczególnego słowa, odwołując się do innych tekstów Pisma, do Ojców Kościoła oraz argumentów rozumowych"41.

37 Por. M. Arias Reyero, Thomas von Aquin als Exeget, s. 255; C. Spicq, Saint Thomas d'Aquin exégète, kol. $727 \mathrm{n}$.

${ }^{38} \mathrm{Na}$ ten temat zob.: M.-D. Chenu, Introduzione allo studio di san Tommaso d'Aquino, s. 281-286; C. Spicq, Esquisse d'une histoire de l'exégèse latine au Moyen Ages, Paris 1944, s. 212218; C. Spicq, Saint Thomas d'Aquin exégète, kol. 715-717.

39 M.-D. Chenu, Introduzione allo studio di san Tommaso d'Aquino, s. 215. Odpowiednimi narzędziami do tej pracy były techniki tekstualne stosowane w gramatyce, retoryce, dialektyce i historii. Pismo Święte „staje się zrozumiałe dzięki tym samym metodom, które kierują interpretacją słów, zdań, obrazów i rodzajów literackich języka” (M.-D. Chenu, La teologia come scienza nel XIII secolo, s. 30).

${ }^{40}$ C. Spicq, Saint Thomas d'Aquin exégète, kol. 715. Ta drobiazgowa egzegeza została wprowadzona, jak się wydaje, przez Hugona z Saint-Cher, a następnie rozwinięta przez św. Alberta Wielkiego i św. Bonawenturę. Zob. C. Spicq, Saint Thomas d'Aquin exégète, kol. 715.

${ }^{41}$ J. A. Weisheipl, Tomasz z Akwinu. Życie, myśl i dzieło, s. 157. 
Można by mnożyć przykłady takiego postępowania. Już na początku Komentarza do Ewangelii św. Jana spotykamy taki przykład. Ewangelia św. Jana przedstawia boskość Chrystusa i dzieli się na dwie części. W pierwszej św. Jan stwierdza bóstwo Chrystusa, a w drugiej potwierdza to przez dzieła dokonane przez Chrystusa. Odnośnie do stwierdzenia bóstwa Chrystusa, po pierwsze ogłasza bóstwo Chrystusa, a po drugie - wyjaśnia sposób, w jaki ono nam się ukazuje. $Z$ kolei to ogłoszenie dokonane jest na dwa sposoby: pierwszy poprzez stwierdzenie, że Chrystus jest Bogiem; drugi poprzez mówienie o wcieleniu Słowa. Następnie, w odniesieniu do tych dwóch rzeczywistości rozważa dwa aspekty: bycie i działanie, a więc mówi o naturze Słowa i Jego działaniu. Na końcu odnośnie do natury Słowa zauważa cztery rzeczy: od kiedy istnieje, gdzie istnieje, kim było i w jaki sposób jest Ono Bogiem ${ }^{42}$.

Łatwo zauważyć, że podział ma cztery stopnie: pierwszy obejmuje całą Ewangelię, a ostatni dociera do znaczenia pojedynczych słów. Następuje szczegółowa analiza dwóch pierwszych uściśleń, które dotyczą kwestii an est i quid est ${ }^{43}$, aby z kolei podjąć trzecie stwierdzenie: „Bogiem było Słowo”" ${ }^{4}$, które jest częścią drugiej kwestii, to jest quid est i oświetla pierwszą.

Konstatacja św. Jana $(1,1)$ jest zatem organicznie połączona $z$ dalszym tekstem $^{45}$. Ta organiczna konstrukcja komentarzy jest innym charakterystycznym znakiem egzegezy scholastycznej, która nie ogranicza się do wyjaśnienia ode-

42 „Evangelista Ioannes, sicut dictum est, intendit principaliter ostendere divinitatem Verbi incarnati; et ideo dividitur istud Evangelium in partes duas. Primo enim insinuat Christi divinitatem; secundo manifestat eam per ea quae Christus in carne fecit, et hoc in cap. 2 Et die tertia. Circa primum duo facit. Primo proponit Christi divinitatem; secundo ponit modum, quo Christi divinitas nobis innotuit, ibi Et vidimus gloriam eius etc. Circa primum duo facit. Primo agit de divinitate Christi; secundo de Verbi Dei incarnatione, ibi Fuit homo missus a Deo. Quia vero in unaquaque re sunt consideranda duo, scilicet esse et operatio, sive virtus ipsius, ideo primo agit de esse Verbi quantum ad naturam divinam; secundo de virtute, seu operatione ipsius, ibi Omnia per ipsum facta sunt. Circa primum quatuor facit. Primo ostendit quando erat Verbum, quia In principio erat Verbum; secundo ubi erat, quia apud Deum; unde dicit Et Verbum erat apud Deum; tertio quid erat, quia Deus; unde subiungit Et Deus erat Verbum; quarto quomodo erat, quia hoc erat in principio apud Deum" (Św. Tomasz z Akwinu, Super Evangelium Ioannis lectura, c. 1, 1. 1, nr 23).

43 Analiza św. Tomasza obejmuje dużą część lectio (Lectio $1 \mathrm{w}$ tekście) i rozciąga się na numery $23-53$.

44 Analiza tego zdania obejmuje numery 53-67 Komentarza.

45 „Attenditur etiam in praemissis verbis congruus ordo: nam in naturali rerum ordine primo invenitur esse, et hoc primo Evangelista insinuavit, dicens In principio erat Verbum, secundo vivere, et hoc est quod sequitur In ipso vita erat; tertio intelligere, et hoc consequenter 
rwanych fragmentów lub niektórych trudnych słów, ale stara się wyjaśnić cały tekst, werset po wersecie, słowo po słowie, pamiętając jednak zawsze o głównej idei, która oświetla szczegóły i je łączy ${ }^{46}$.

Według Marie-Dominique Chenu nieustanne poszukiwanie motywów i pytanie o podstawy jest szczytem tej egzegezy ${ }^{47}$. W Prologu Komentarza do Ewangelii św. Jana św. Tomasz ukazuje ratio, czyli wyjaśnienie, w jakim celu napisana została ta Ewangelia ${ }^{48}$. Księga Hioba ma na celu per probabiles rationes ukazać, że Opatrzność Boża kieruje życiem człowieka ${ }^{49}$.

Po podziale tekstu św. Tomasz przechodzi do jego wyjaśnienia. Czyni to przez dosłowną analizę ${ }^{50} \mathrm{i}$ dociekania w oparciu o tekst ${ }^{51}$. Przykładem tego typu postępowania może być fragment Komentarza do Ewangelii św. Jana, w którym św. Tomasz analizuje przyimek „przez”, w wyrażeniu: „Wszystko przez Nie się stało" $(\mathrm{J} 1,3)^{52}$. Dlatego komentarze biblijne św. Tomasza - po-

adiunxit Vita erat lux hominum" (Św. Tomasz z Akwinu, Super Evangelium Ioannis lectura, c. 1, 1. 3 , $\mathrm{nr} 100)$.

${ }^{46}$ Por. C. Spicq, Saint Thomas d'Aquin exégète, kol. 716n. C. M. J. Vansteenkiste nazywa ją „metodą twórczą”, ponieważ poszukuje ona porządku i jedności. Por. C. M. J. Vansteenkiste, Il metodo di san Tommaso, s. 190.

47 M.-D. Chenu, Introduzione allo studio di san Tommaso d'Aquino, s. $217 \mathrm{n}$.

48 „Quia cum Evangelistae alii tractent principaliter mysteria humanitatis Christi, Ioannes specialiter et praecipue divinitatem Christi in Evangelio suo insinuat, ut supra dictum est: nec tamen praetermisit mysteria humanitais; quod ideo factum est, quia postquam alii Evangelistae sua Evangelia scripserunt, insurrexerunt haereses circa divinitatem Christi, quae erat quod Christus erat purus homo, sicut Ebion et Cerintus falso opinabantur. Et ideo Ioannes Evangelista, qui veritatem divinitatis Verbi ab ipso fonte divini pectoris hauserat, ad preces fidelium, Evangelium istud scripsit, in quo doctrinam de Christi divinitate nobis tradidit, et omnes haereses confutavit" (Św. Tomasz z Akwinu, Super Evangelium Ioannis lectura. Prologus s. Thomae, nr 10).

49 „...primus ponitur liber Job: cuius intentio in hoc versatur, ut per probabiles rationes ostendatur res humanas divina providentia regi" (Św. Tomasz z Akwinu, Expositio in Librum Sancti Job. Prologus s. Thomae, t. 18, s. 2, przypis 492).

${ }^{50} \mathrm{Na}$ temat egzegezy dosłownej zob. C. Spicq, Saint Thomas d'Aquin exégète, kol. $725 \mathrm{n}$. Na przykład: „Cui nomen erat Ioannes, quod interpretatur «in quo est gratia»” (Św. Tomasz z Akwinu, Super Evangelium Ioannis lectura, c. 1, 1. 4, nr 114). W tej egzegezie Akwinata wychodzi od przekonania, że Pismo Święte napisane jest powszechnie używanym językiem, a więc własne znaczenie wyjaśnianych słów jest powszechne („Secundum opinionem populi loquitur Scriptura" [Św. Tomasz z Akwinu, Summa Theologiae, 1-2, q. 98, a. 3, ad 2]).

${ }^{51}$ Także ten element jest właściwością egzegezy scholastycznej. Por. M.-D. Chenu, Introduzione allo studio di san Tommaso d'Aquino, s. 134n.

${ }^{52}$ Sic ergo cum dicitur Omnia per ipsum facta sunt; si ly per denotet efficientiam causam, seu moventem Patrem ad operandum, dicendum est quod Pater nihil operatur per Filium, 
dobnie jak i innych autorów tego okresu - obfitują w kwestie. W komentarzu zdania: „Nie w mądrości słowa, by nie zniweczyć Chrystusowego krzyża” (1 Kor 1, 17b), św. Tomasz stawia kwestię, to znaczy problem do rozwiązania, co oznacza „mądrość słowa”. Na początku Akwinata zastanawia się, co może oznaczać to wyrażenie i przytacza dwie możliwości. Szybko jednak dodaje sed contra, a więc coś, co sprzeciwia się poprzednim i wprowadza inną możliwość. Jednakże i ona zostaje zanegowana przez przykład doktorów Kościoła. W końcu Doktor Anielski daje swoje wyjaśnienie (dicendum est ergo), w którym dokonuje koniecznych rozróżnień i przedstawia rozwiązanie, powołując się na autorytet św. Augustyna ${ }^{53}$. A więc przez opozycje, rozróżnienia, definicje dochodzi do głębszego zrozumienia tekstu ${ }^{54}$.

Podobnie jak ojcowie, Akwinata wykorzystuje w sacra doctrina filozofię $e^{55}$. Rozum pomaga zrozumieć tekst święty, aczkolwiek jego rola nie jest

sed per seipsum omnia operatur, ut dictum est. Si vero ly per denotet causam formalem, sic cum Pater operetur per sapientiam suam, quae est sua essentia, operatur per suam sapientiam, sicut operatur per suam essentiam; et quia sapientia et virtus Patris attribuitur Filio [...], ideo appropriate dicimus quod Pater omnia oparatur per Filium, idest per sapientiam suam [...]. Si vero ly per denotat causalitatem ex parte operati, tunc hoc quod dicimus «Pater omnia operari per Filium» non est appropriatum Verbo, sed proprium eius, quia hoc quod est causa creaturarum, habet ab alio, scilicet a Patre, a quo habet esse" (Św. Tomasz z Akwinu, Super Evangelium Ioannis lectura, c. 1, 1. 2, nr 76). Przytoczony fragment jest częścią szerszego wyjaśnienia przyczynowości.

53 „Dicit ergo primo: Dixi quod misit me Christus evangelizare, non tamen ita quod ego in sapientia verbi evangelizem, id est, in sapientia mundana [...]. Vel sapientiam verbi nominat rethoricam [...]. Sed contra dicitur [...]. Sed quia in Graeco ponitur «logos» [...], posset convenientius intelligi sapientia verbi, id est humanae rationis [...]. Sed contra hoc videtur [...]. Dicit enim Hieronymus [...]. Et Augustinus [...]. Dicendum est ergo quod aliud est docere in sapientia verbi quocumque modo intelligatur, et aliud uti sapientia verbi in docendo. Ille in sapientia verbi docet qui sapientiam verbi accipit pro principali radice suae doctrinae, ita scilicet quod ea solum approbet, quae verbi sapientiam continent: reprobet autem ea quae sapientiam verbi non habent, et hoc fidei est corruptivum. Utitur autem sapientia verbi, qui suppositis verae fidei fundamentis, si qua vera in doctrinis philosophorum inveniat, in obsequium fidei assumit. Unde Augustinus dicit in secundo «De Doctrina Christiana» (2, c. 40), quod [...]" (Św. Tomasz z Akwinu, Super Primam Epistolam ad Corinthios lectura, c. 1, 1. 3, nr 41-43).

${ }^{54}$ Por. M.-D. Chenu, Introduzione allo studio di san Tommaso d'Aquino, s. 137nn, 148n.

55 Św. Tomasz zauważa, że w sacra doctrina możemy posłużyć się filozofią na trzy sposoby. Po pierwsze, by ukazać to, co przygotowuje wiarę (praeambula fidei). Po drugie, by pokazać prawdy wiary poprzez analogie z prawdami naturalnymi. Po trzecie, by bronić wiary. Por. A. Cirillo, Cristo Rivelatore del Padre nel Vangelo di s. Giovanni secondo il Commento dis Tommaso d'Aquino, Roma 1988, s. 56-62. 
decydująca ${ }^{56}$. Z tym zastosowaniem łączy się także analiza czterech przyczyn: sprawczej, materialnej, formalnej i celowej. Można to zobaczyć w komentarzach do listów św. Pawła i do Księgi proroka Jeremiasza. Na przykład we wprowadzeniu do Listu do Efezjan Akwinata rozróżnia: przyczyną sprawczą jest Paweł, celową potwierdzenie jedności, materialną Efezjanie, formalną plan listu ${ }^{57}$.

Nie tylko drobiazgowa analiza charakteryzuje egzegezę scholastyczną. Trzeba pamiętać również o wysiłku dokonywania syntezy ${ }^{58}$, jak to już można było zauważyć, gdy chodzi o ideę główną. Dotyczy to także fragmentów tekstu ${ }^{59}$.

W tym kontekście trzeba wspomnieć także szczególną troskę św. Tomasza o język. Jego język był bardziej logiczny i bardziej racjonalny od języka poprzedników, a w konsekwencji pozwalał łatwiej unikać zamieszania ${ }^{60}$. Sam Tomasz odczuwał jednak nieadekwatność niektórych słów do wyrażenia pewnej myśli, jak to widać w wyrażeniach typu: quodammodo, quasi ${ }^{61}$. Starał się ciągle o doprecyzowanie i udoskonalenie swego języka ${ }^{62}$, który odznaczał się wstrzemięźliwością ${ }^{63}$, ale $\mathrm{z}$ tego powodu nie przestawał być piękny ${ }^{64}$.

${ }^{56}$ „Haec expositio in hoc videtur deficere, quod asserit quaedam per Scripturam sacram intelligi, quorum contraria satis evidentibus rationibus probantur" (Św. Tomasz z Akwinu, Quaestio disputata De Potentia, q. 4, a. 1, ad 5).

57 „Iam apparet quae sit causa huius epistolae efficiens, quia Paulus, quod notatur ibi Ego. Finalis, quia confirmatio, quod notatur confirmavi. Materialis, quia Ephesii, quod notatur ibi columnas eius. Formalis patet in divisione epistolae, et modo agendi" (Św. Tomasz z Akwinu, Super Epistolam ad Ephesios lectura. Prologus, nr 41-43, w: Super Epistolas Pauli lectura, dz. cyt.).

${ }^{8}$ Por. A. Gardeil, La réforme de la théologie catholique. Les procédés exégètiques de Saint Thomas, „Revue Thomiste” 15 (1903), s. 452n.

59 „Supra Dominus assignavit causam spiritualis regenerationis quantum ad descensum Filii, et exaltationem Filii hominis, et posuit fructum, scilicet vitam aeternam, qui quidem fructus incredibilis videbatur hominibus habentibus necessitatem moriendi: et ideo Dominus hoc manifestat, et primo probat magnitudinem fructus ex magnitudine divini amoris; secondo excludit quamdam responsionem, ibi ( $\mathrm{nr} 481$ ). Non enim misit Deus Filium suum in mundum, ut iudicet mundum" (Św. Tomasz z Akwinu, Super Evangelium Ioannis lectura, c. 1, 1. 3, nr 476).

${ }^{60}$ Por. H. de Lubac, Esegesi medievale, t. 4, Roma 1962-1972, s. 1462 n.

${ }^{61}$ Por. M.-D. Chenu, Introduzione allo studio di san Tommaso d'Aquino, s. 102n.

${ }^{62}$ Por. M. Arias Reyero, Thomas von Aquin als Exeget, s. 147n.

${ }_{3}^{63}$ Por. I. Biffi, La Teologia e un Teologo: San Tommaso d'Aquino, s. 56.

${ }^{64}$ Por. J. Pieper, Guide to Thomas Aquinas, Notre Dame, Indiana 1987, s. 81. 


\section{Egzegeza patrystyczna}

Trzecią charakterystyczną cechą egzegezy św. Tomasza jest egzegeza według tradycji patrystycznej ${ }^{65}$. Konieczność odwołania się do ojców podkreśla sam Akwinata $^{66}$, według którego trzeba nie tylko zachować to, co zawarte jest w Piśmie Świętym, ale także strzec nauk świętych doktorów, którzy zachowali nietknięte Pismo Święte ${ }^{67}$. Patrystyczny charakter egzegezy św. Tomasza wyraża się w dwojaki sposób. Po pierwsze - Doktor Powszechny przyjmuje metody tradycyjnej egzegezy i stara się je ulepszyć ${ }^{68}$. Po drugie - wyjaśnienia ojców są dla niego pomocą w interpretacji trudniejszych ustępów i dają możliwość weryfikowania własnej egzegezy w świetle Tradycji Kościoła ${ }^{69}$.

Na przykład w komentarzu zdania: „Czyż to moja lub Twoja sprawa, Niewiasto? Czyż jeszcze nie nadeszła godzina moja?”. Doktor Anielski odrzuca, między innymi, błąd manichejczyków i Walentyna, którzy nauczali, że Chrystus nie miał prawdziwego ciała, lecz tylko pozorne i niebieskie. Po przytoczeniu argumentu z Pisma Świętego Akwinata przechodzi do argumentu patrystycznego, który służy mu do wzmocnienia i zilustrowania własnego wyjaśnienia ${ }^{70}$.

${ }^{65}$ Por. C. Spicq, Saint Thomas d'Aquin exégète, kol. 722n, 728. Por. także: G. Geenen, Le fonti patristiche come «autorità» nella teologia di s. Tommaso, „Sacra Doctrina” 20 (1975), s. 7-67; G. Geenen, Saint Thomas et les Pères, w: Dictionaire de théologie catholique, t. 15, kol. 738-761.

${ }^{66}$ „Haec autem eruditio hominum ex Scripturis non potest nisi per expositiones Sanctorum” (Św. Tomasz z Akwinu, Quaestiones Quodlibetales 12, q. 17, a. 1). „Intellectus sacrae Scripturae ex actibus sanctorum intelligitur" (Św. Tomasz z Akwinu, Super Epistolam ad Romanos lectura, c. $1,1.5, \mathrm{nr} 80$ ).

${ }^{67}$ „Quia nos, a sacra Scriptura recipientes manifestationem Dei, ea quae in sacra Scriptura sunt posita, oportet nos custodire sicut quamdam optimam regulam Veritatis, ita quod neque multilicemus, addentes; neque minoremus, subtrahentes; neque pervertamus, male exponentes; quia dum nos custodimus sancta ab ipsis custodimur et ab ipsis confirmamur ad custodiendum eos qui custodiunt sancta. Oportet enim non solum conservare ea quae in sanctis Scripturis sunt tradita [...], sed et ea quae dicta sunt a sacris Doctoribus, qui sacram Scripturam illibatam conservaverunt" (Św. Tomasz z Akwinu, In Dionysii De divinis nominibus, c. 2, 1. 1, nr 125, Taurini-Romae 1950).

${ }^{68}$ Por. M. Arias Reyero, Thomas von Aquin als Exeget, s. 87nn, $139 \mathrm{n}$.

${ }^{69}$ Por. G. Ferraro, Il tema dello Spirito Santo nel Commento di San Tommaso d'Aquino agli Ebrei (annotazioni di dottrina e di esegesi tomista), w: San Tommaso d'Aquino nel suo settimo centenario, s. 89n.

$7^{70}$ „Manichei namque dicunt Christum non habuisse verum corpus, sed phantasticum. Valentinus asserit Christum attulisse corpus caeleste, dicens quod, quantum ad corpus, Christus nihil pertinet ad Virginem. Et huius erroris fulcimentum sumit per hoc quod dicit ei Iesus. Quid mihi et tibi est, mulier? Quasi dicat: Nihil a te suscepi. Sed hoc est contra auctoritatem 
Święty Tomasz nie tylko odwołuje się do autorytetu ojców, lecz także ściśle określa naturę i autorytet teologiczny tej metody ${ }^{71}$. W Sumie teologicznej znajdujemy tezę, według której ci, którzy żyli bliżej czasów Chrystusa, poznali bardziej tajemnice wiary ${ }^{72}$. Ojcowie są więc autorytetami i sacra doctrina posługuje się nimi, jako własnymi argumentami, aczkolwiek są to argumenty prawdopodobne $^{73}$. Nie ma konieczności wierzenia w twierdzenia komentatorów. Trzeba wierzyć tylko w kanoniczne Pismo ${ }^{74}$. Jednakże pożyteczne jest „odwoływanie się do ojców”, nawet „Z zastrzeżeniami odnośnie do ich opinii i oceny”75.

Fakt, że ojcowie są tylko maiores nostri, których autorytet opiera się na autorytecie Kościoła, wpływa na sposób posługiwania się nimi. Widać przede wszystkim wolność, jaką przejawia św. Tomasz wobec autorytetów ludzkich ${ }^{76}$. „Św. Tomasz często powtarza, że «zdrowe poznanie ojców» jest regułą wykorzystania ich tekstów, tak jak Kościół posiada «zdrowe poznanie Pism»"77.

sacrae Scripturae: dicit enim Apostolus, Gal 4,4: Misit Deus Filium suum, factum ex muliere: non enim posset dici ex ea factus, nisi ex ea aliquid sumpsisset. Arguit praeterea contra eos Augustinus, dicens: "Quomodo scis, quod Dominus dixit Quid mihi et tibi? Respondens, quia Ioannes Evangelista hoc narrat. Sed ipse etiam Evangelista dicit de Virgine quod erat mater eius. Si ergo credis Evangelistae in eo quod narrat Iesum dixisse matri: Quid mihi et tibi est, mulier? credas etiam in hoc ei quod dicit: Et erat mater Iesu ibi»" (Św. Tomasz z Akwinu, Super Evangelium Ioannis lectura, c. 2, 1. 1, nr 349).

${ }_{71}$ Por. C. Spicq, Saint Thomas d'Aquin exégète, kol. 728.

72 „Et ideo illi qui fuerunt propinquiores Christo [...], plenius misteria fidei cognoverunt” (Św. Tomasz z Akwinu, Summa Theologiae, 2-2, q. 1, a. 7, ad 4).

73 „Sacra doctrina auctoritatibus (philosophorum) utitur quasi extraneis argumentis, et probabilibus. Auctoritatibus autem canonicae Scripturae utitur proprie, ex necessitate argumentando. Auctoritatibus autem aliorum doctorum Ecclesiae, quasi arguendo ex propriis, sed probabiliter" (Św. Tomasz z Akwinu, Summa Theologiae, 1, q. 1, a. 8, ad 2).

74 „Dicta expositorum necessitatem non inducunt quod necesse est eis credere, sed solum Scriptura canonica, quae in Veteri et Novo Testamento est (Św. Tomasz z Akwinu, Quaestiones Quodlibetales 12, q. 17, a. 1).

${ }^{75}$ G. Geenen, Le fonti patristiche come «autorità» nella teologia di s. Tommaso, s. 28. Ojcowie nie otrzymali daru natchnienia i nie było im dane Objawienie. Są więc maiores nostri (G. Geenen, Le fonti patristiche come «autorità» nella teologia di s. Tommaso, s. 22n). Tylko Pismo Święte i autorytet Kościoła św. Tomasz traktuje w inny sposób („Maximam habet auctoritatem Ecclesiae consuetudo, quae semper est omnibus aemulanda. Quia et ipsa doctrina Catholicorum Doctorum ab Ecclesia auctoritatem habet; unde magis standum est auctoritati Ecclesiae quam auctoritati vel Augustini vel Hieronymi vel cuiuscumque Doctoris" [Św. Tomasz z Akwinu, Summa Theologiae, 2-2, q. 10, a. 12]).

${ }^{76}$ Por. C. Allegro, Il metodo e il pensiero di san Tommaso d'Aquino, Roma 1978, s. 136.

77 G. Geenen, Le fonti patristiche come «autorità» nella teologia di s. Tommaso, s. 31n. 
Akwinata „Z szacunkiem”78 przedstawia wyjaśnienia ojców, ale niejednokrotnie prezentuje własną opinię, także wtedy, gdy ojcowie są jednomyślni w jakimś wyjaśnieniu ${ }^{79}$. Doktor Powszechny posługuje się nauczaniem ojców w sposób wolny i bardzo osobisty, ponownie rozważając i panując nad ich propozycjami ${ }^{80}$.

Doktor Anielski nie ogranicza się do powtórzenia tekstu jakiegoś ojca, ale widzi go w kontekście swojej myśli, a więc włącza go w swoje wyjaśnienie ${ }^{81}$. Ale zdarza się także, że św. Tomasz przytacza dwa wyjaśnienia ojców, nie zajmując własnego stanowiska ${ }^{82}$.

Według Godefrido Geenena Akwinata korzysta z ojców na różne sposoby: raz przywołuje ich jako zwyczajne przedstawienie lub wzmocnienie interpretacji świętych tekstów; innym razem są oni dla niego źródłem doktryny; jeszcze innym razem stanowią dowód lub potwierdzenie doktryny; wreszcie

78 „Unde si qua in dictis antiquorum doctorum inveniuntur quae cum tanta cautela non dicantur quanta a modernis servatur, non sunt contemnanda aut abicienda; sed nec etiam ea extendere oportet, sed exponere reverenter" (Św. Tomasz z Akwinu, Contra errores Graecorum, Pars Prior, nr 1029, w: Opuscula Theologica, t. 1, Taurini-Romae 1954).

79 „Sciendum autem, quod omnes Sancti communiter haec exponunt de Christo [...]. Posset autem exponi totum ad litteram, ut induceretur Dominus metaphorice, quasi veniens ad delendos diversos populous hostes Judaeorum, et praecipue Idumaeos, secundum modum metaphoricum qui habitus est. Supra, 59,17: Indutus est iustitia ut lorica" (Św. Tomasz z Akwinu, Expositio super Isaiam, c. 63, nr 1-2, Ed. Typographia S.C. de Propaganda Fide, Romae 188o, s. 226, 228).

${ }^{80}$ Por. G. Geenen, Saint Thomas et les Pères, kol. 752. Często w komentarzach pojawiają się wyrażenia: „Sed melius dicendum est, secundum Chrysostomum” (Św. Tomasz z Akwinu, Super Evangelium Ioannis lectura, c. 12, 1. 4, nr 1632). „Secundum Augustinum [...]. Sed hoc non videtur multum ad propositum pertinere [...]. Et ideo melius dicendum, secundum Chrysostomum" (Św. Tomasz z Akwinu, Super Evangelium Ioannis lectura, c. 11, 1. 7, nr 1571).

${ }^{81}$ Por. M. Arias Reyero, Historia y teología. La interpretación de la Escritura en santo Tomás, S. 515 .

${ }_{82}$ „Consequenter cum dicit Et vidit, et credidit, ponitur effectus inquisitionis. Et in primo aspectu posset talem sensum habere, quod vidit illa scilicet et credidit quod Christus resurrexit. Sed, secundum Augustinum, hoc non potest stare; quia sequitur Nondum enim sciebant Scripturam etc. Ideo dicendum, quod vidit vacuum monumentum, et credidit his quae dixerat mulier, scilicet quod aliqui Dominum asportassent [...]. Vel, secundum Chrysostomum, vidit linteamina posita sic ordinata, quod non fuisset factum, si corpus furtim fuisset sublatum, et credidit, scilicet vera fide, quod Christus a morte resurrexit. Et tunc hoc quod sequitur Nondum enim sciebant Scripturam, refertur ad hoc quod dicit Vidit, et credidit, quasi diceret: Antequam videret non sciebat Scripturam, quia oportebat eum a mortuis resurgere. Sed quando vidit, credidit quod a mortuis resurrexisset" (Św. Tomasz z Akwinu, Super Evangelium Ioannis lectura, c. 20, 1. 1, nr 2488n). 
także czasem odwołanie do ojców Kościoła stanowi ozdobę, wyjaśnienie lub usprawiedliwienie ${ }^{83}$.

Na koniec trzeba dodać, że św. Tomasz nie tylko „mówi jasno o wartości źródeł doktryny teologicznej”" ${ }^{\prime 4}$, lecz także daje dobry przykład odwoływania się do ojców w egzegezie ${ }^{85}$.

\section{Egzegeza teologiczna}

Egzegeza św. Tomasza ma charakter ściśle teologiczny ${ }^{86}$. Dla Akwinaty „nie była [ona] nauką pomocniczą teologii, lecz samą w sobie teologią" ${ }^{87}$. W swej egzegezie starał się on ukazać pełną treść doktrynalną i moralną tekstu ${ }^{88}$. Charakter teologiczny egzegezy Doktora Anielskiego wyraża się przez poszukiwanie „porządku i jedności” wokół jakiejś idei teologicznej. W ten sposób, na przykład Komentarz do Ewangelii św. Mateusza zbudowany jest wokół idei humanitas Christi, Komentarz do Ewangelii św. Jana wokół idei divinitas Verbi, a Komentarz do listów św. Pawła jest zbudowany wokół pojęcia gratia Christ $i^{89}$. Egzegeza teologiczna umożliwiała rozwiązanie trudności, dostarczała argumentów dla tez doktrynalnych lub wyjaśniała treści wiary ${ }^{90}$. Na przykład zdanie: „Jezus [...] rzekł do Filipa: «Gdzie kupimy chleba, aby oni się najedli?» A mówił to, wystawiając go na próbę" $(\mathrm{J} 6,5-6)$, stawia kwestię wiedzy Jezusa, ponieważ można by pomyśleć, że Chrystus pyta dlatego, że nie wie. Doktor Anielski znajduje rozwiązanie w pogłębieniu teologicznym stwierdzenia Ewangelisty: „A mówił to, wystawiając go na próbę"1. Na podstawie

\footnotetext{
${ }^{83}$ Por. G. Geenen, Saint Thomas et les Pères, kol. 749nn.

${ }^{84}$ G. Geenen, Saint Thomas et les Pères, kol. 738.

${ }^{85} \mathrm{Na}$ przykład św. Tomasz w Komentarzu do Ewangelii św. Jana 435 razy cytuje ojców łacińskich i 291 razy ojców greckich. Por. A. Cirillo, Cristo Rivelatore del Padre nel Vangelo di s. Giovanni secondo il Commento di s. Tommaso d'Aquino, s. 11. Warto w tym miejscu także wspomnieć Expositio continua in Matthaeum, Marcum, Lucam, Joannem, tj. o Catena aurea, które jest „komentarzem złożonym jedynie z tekstów ojców i doktorów Kościoła” (C. Spicq, Saint Thomas d'Aquin exégète, kol. 722).

${ }^{86}$ Por. M. Arias Reyero, Thomas von Aquin als Exeget, s. 258.

${ }^{87}$ H. de Lubac, Esegesi medievale, t. 2, s. 119.

${ }^{88}$ Por. C. Spicq, Saint Thomas d'Aquin exégète, kol. 717, 736.

${ }^{89}$ Por. C. M. J. Vansteenkiste, Il metodo di san Tommaso, s. 190 .

${ }^{\circ}$ Por. C. Spicq, Saint Thomas d'Aquin exégète, kol. 717nn.

${ }^{91}$ Są różne rodzaje prób, wyjaśnia Doktor Powszechny. Inaczej wystawiają na próbę człowiek, diabeł i Bóg. Człowiek - aby się więcej nauczyć. Diabeł - by zwieść. Natomiast Bóg i Chrystus
} 
słów: „Ponieważ z nieba zstąpiłem nie po to, aby pełnić swoją wolę, ale wolę Tego, który Mnie posłał" (J 6,38) można by widzieć w Chrystusie tylko człowieka, gdyż Jego wola jest odróżniona od woli Ojca. Trzeba jednak pamiętać, że w Chrystusie są dwie wole: wola boska i wola ludzka ${ }^{92}$.

Z kolei doktryna teologiczna już mocno utwierdzona pomaga wyjaśnić i doprecyzować sens dosłowny. Na przykład doktryna o potrójnej wiedzy Chrystusa (zmysłowej, intelektualnej i boskiej) pozwala wyjaśnić i pogłębić sens dosłowny słowa „prorok” w zdaniu: „A kiedy ludzie spostrzegli, jaki znak uczynił Jezus, mówili: «Ten prawdziwie jest prorokiem, który ma przyjść na świat»” (J 6, 14 $)^{93}$.

wystawiają na próbę, aby inni mogli zdobyć doświadczenie dzięki próbie. Filip jest wystawiony na próbę, ponieważ przekazując innym swoją odpowiedź, doprowadzi ich do pewnego rozpoznania przyszłego znaku („Intentio autem interrogantis aperitur cum dicit Hoc autem dicebat tentans eum etc. Ubi Evangelista unam dubitationem excludens, ducit in aliam. Potuisset enim dubitari quod Dominus Philippum quasi ignorans interrogasset; sed hoc excludit dicens Ipse enim sciebat quid esset facturus. Sed cum tentare videatur etiam ignorantis esse, cum idem sit quod experimentum sumere, videtur quod Evangelista in aliam dubitationem inducat cum dicit Tentans eum. Sed diecndum, quod diversimode aliquis tentat aliquem, ut experimentum de eo sumat: aliter enim tentat homo, quia ut addiscat; aliter diabolus, quia ut decipiat [...]. Deus vero et Christus tentat quidem non ut addiscat, quia ipse est qui scrutatur corda et renes; non ut decipiat, quia ipse neminem tentat, ut dicitur Iac 1,13; sed tentat ut aliis experimentum de tentato tribuat [...]. Ita ex hoc Philippum tentat ut insinuaret aliis suam responsionem, inducens per hoc eos in certissimam futuri signi cognitionem" [Św. Tomasz z Akwinu, Super Evangelium Ioannis lectura, c. 6, 1. 4, nr 850]).

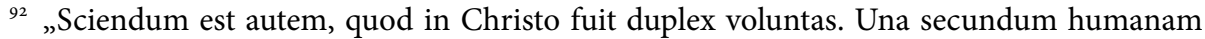
naturam, quae est sibi propria, et natura, et voluntate Patris; alia secundum naturam divinam, quae est eadem cum voluntate Patris. Voluntatem ergo suam, scilicet humanam, ordinavit sub voluntate divina, quia obedientiam suam sub effectu paternae voluntatis ostendit ipse, volens voluntatem Patri explere" (Św. Tomasz z Akwinu, Super Evangelium Ioannis lectura, c. 6, 1. 4, nr 923).

${ }_{93}$ Wiedza Chrystusa była potrójna: zmysłowa, intelektualna i boska. Zgodnie z tą zmysłową Chrystus był trochę podobny do proroków, o ile w Jego wyobraźni mogły się tworzyć obrazy zmysłowe, które przedstawiały rzeczy przyszłe lub zakryte. Następnie miał wiedzę intelektualną. Zgodnie z nią nie był podobny do proroków; co więcej był ponad aniołami, ponieważ był comprehensor doskonalszy od jakiegokolwiek stworzenia. Ponadto Jego wiedza była także boska. Zgodnie z nią Chrystus był natchnieniem proroków i aniołów, ponieważ wszelka wiedza ma swą przyczynę w uczestnictwie w Słowie Bożym („In Christo autem fuit triplex cognitio. Scilicet sensitiva: et secundum hanc habuit aliquam similitudinem cum Prophetis, inquantum in imaginatione Christi formari poterant aliquae species sensibiles, quibus futura vel occulta praesentarentur, praecipue propter passibilitatem, quae sibi conveniebat propter statum viatoris. Item cognitio intellectiva: et quantum ad hanc non habet similitudinem cum Prophetis; sed etiam est supra angelos, quia erat comprehensor excellentius quam aliqua creatura. Item 
Także rozumowe pogłębienie treści objawionych pomaga pojąć dosłowny sens tekstu i dostarcza materiału dla wyjaśnienia prawd wiary ${ }^{94}$. Przykład znajdujemy w opowiadaniu o uzdrowieniu chromego nad sadzawką Betesda (por. J 5, 1-18). Sadzawka była zapowiedzią chrztu ${ }^{95}$. Komentarz daje okazję dla rozważań o sakramencie chrztu, o jego naturze i mocy oraz o głównym działającym, którym w sakramencie chrztu jest Trójca Święta ${ }^{96}$.

Także całe perykopy biblijne dają Akwinacie okazję do egzegezy teologicznej. Na przykład opis uzdrowienia syna urzędnika królewskiego (por. J 4, 46-54) pozwala mu wyjaśnić drogę wiary. $\mathrm{W}$ istocie wiara (w tym wypadku urzędnika królewskiego) jest elementem, do którego św. Tomasz powraca w ciągu całego fragmentu. Pokazuje jej stan początkowy, jej wzrost i udoskonalenie podczas spotkania z Chrystusem, i w końcu jej pełnię ${ }^{97}$. W kontekście refleksji

cognitio divina: et quantum ad hanc fuit Prophetarum et angelorum inspirator, cum omnis cognitio causetur per participationem Verbi divini" [Św. Tomasz z Akwinu, Super Evangelium Ioannis lectura, c. 6, 1. 2, nr 868]).

94 Por. C. Spicq, Saint Thomas d'Aquin exégète, kol. 718.

95 "Mystice autem, secundum Chrysostomum, haec piscina baptismum praefigurabat” (Św. Tomasz z Akwinu, Super Evangelium Ioannis lectura, c. 5, 1. 1, nr 703).

${ }_{96}$ „Et quidem virtus piscinae in aliquo concordat cum baptismo, et in aliquo differt. Concordat quidem in duobus. Primo quidem in occultatione virtutis: nam virtus aquae huius piscinae non erat ex natura sua, alias semper sanasset, sed ex aliqua virtute occulta, scilicet ex angelo [...]. Et similiter aqua baptismi, ex eo quod aqua non habet virtutem purgativam animarum, sed ex occulta virtute Spiritus sancti [...]. Secundo concordat in effectu, quia sicut aqua baptismi sanat, ita et ista piscina sanabat [...]. Differt autem quantum ad tria. Primo quantum ad id cuius virtute hoc fiebat: quia aqua piscinae conferebat sanitatem virtute angeli; aqua vero baptismi virtute increata, non solum Spiritus sancti, sed etiam Trinitatis [...]. Secundo differt quantum ad efficaciam: quia aqua piscinae non habuit virtutem sanativam continue, sed secundum tempus, idest determinato tempore; aqua vero baptismi continuam abluendi virtutem habet [...]. Tertio quantum ad multitudinem sanandorum: quia ad motum aquae ilius piscinae, sanabatur tantum unus; sed ad motum aquae baptismi sanantur omnes" (Św. Tomasz z Akwinu, Super Evangelium Ioannis lectura, c. 5, 1. 1, nr 707).

97 „Regulus iste adhuc non credebat perfecte: erat enim in eo duplex defectus fidei. Unus, quia licet crederet Christum esse verum hominum, non tamen credebat eum habere virtutem divinam; alias credidisset eum absentem posse sanare [...]. Et sic non rogasset eum quod descenderet in domum suam, sed quod mandaret tantum. Secundus defectus fuit, quia, secundum Chrysostomum, dubitabat utrum Christus sanare posset filium suum: nam si pro certo hoc credidisset, non expectasset adventum Christi ad terram suam, sed ipse potius ivisset in Iudaeam. Sed modo quasi desperatus de salute filii, nolens negligere quidquid circa hoc facere posset, abiit ad eum more parentum, qui desperantes de salute filiorum, etiam imperitos medicos consulunt" (Św. Tomasz z Akwinu, Super Evangelium Ioannis lectura, c. 4, 1. 7, nr 684). „Ostenditur in hoc perfectus fidei eius quantum ad aliquid, quia scilicet vocat eum Dominum: 
nad wiarą tego urzędnika Akwinata zachęca chrześcijan do ciągłego wysiłku doskonalenia swej wiary i zjednoczenia z Chrystusem ${ }^{98}$.

W końcu - jak twierdzi Ceslas Spicq - egzegeza św. Tomasza jest egzegezą teologiczną także w tym sensie, że tekst biblijny dostarcza argumentów o prawdach wiary ${ }^{99}$. Na przykład wielka mowa o chlebie życia (por. J 6, zwłaszcza 6, 49-52) pozwala na pewne spostrzeżenia o sakramencie Eucharystii, o jego naturze, o jej Autorze, o jej prawdzie i pożytku, o jej skuteczności w stosunku do chrztu i o jej przyjmowaniu ${ }^{100}$.

Do tych aspektów należy dołączyć interpretację Pisma Świętego w kluczu apologetycznym. Ta nowa linia egzegezy teologicznej, która pojawia się w xıI wieku, $\mathrm{w}$ następnym stuleciu jest uważana za jeden $\mathrm{z}$ celów egzegezy ${ }^{101}$. W istocie Doktor

licet non totaliter in fide profecerit, adhuc enim corporalem praesentiam Christi ad salutem filii sui necessariam credens, rogabat eum ut descenderet” (Św. Tomasz z Akwinu, Super Evangelium Ioannis lectura, c. 4, 1. 7, nr 686). „Obedientia reguli ponitur quantum ad duo. Primo quia annuntianti credidit [...]. Secundo vero, quia mandato obedivit [...], proficiendo in fide, licet adhuc neque integre neque sane, ut Origenes dicit" (Św. Tomasz z Akwinu, Super Evangelium Ioannis lectura, c. 4, 1. 7, nr 690). „Sed quia regulus neque integre neque sane adhuc credebat, adhuc volebat scire utrum casu an praecepto Christi filius curatus esset: et ideo tempus curationis inquirit” (Św. Tomasz z Akwinu, Super Evangelium Ioannis lectura, c. 4, 1. 7, nr 694). „Patet autem ex hoc quod fides istius semper profecit: nam a principio quando interpellavit pro filio infirmo, debilis erat; postea plus firmitatis habere coepit, quando vocavit eum Dominum; deinde quando credidit homo sermoni, et ibat, magis perfecta erat; tamen non integre, quia adhuc dubitavit. Hic, cognita manifeste Dei virtute in Christo, perficitur in eius fide, quia ut dicitur Prov 4,18: Iustorum semita quasi lux splendens procedit, et crescit usque ad perfectum diem" (Św. Tomasz z Akwinu, Super Evangelium Ioannis lectura, c. 4, 1. 7, nr 697).

${ }^{98}$ „Oportet nos proficiendo ire: quia qui stat, exponit se periculo ut vitam gratiae conservare non possit; in via enim Dei non proficere, deficere est” (Św. Tomasz z Akwinu, Super Evangelium Ioannis lectura, c. 4, 1. 7, nr 690).

${ }^{99}$ Por. C. Spicq, Saint Thomas d'Aquin exégète, kol. 719n.

${ }^{100}$ Por. Św. Tomasz z Akwinu, Super Evangelium Ioannis lectura, c. 6, 1. 6, nr 960-964. „Ubi possumus quatuor considerare circa ipsum sacramentum: scilicet speciem, instituentis auctoritatem, sacramenti veritatem, et eius utilitatem" (Św. Tomasz z Akwinu, Super Evangelium Ioannis lectura, c. 6, 1. 6, nr 960).

${ }^{101}$ Por. C. Spicq, Esquisse d'une histoire de l'exégèse latine au Moyen Ages, s. 232n; C. Spicq, Saint Thomas d'Aquin exégète, kol. 723. Odrzucenie błędów było jednym z trzech celów sacra doctrina („Ex istis autem principiis ad tria proceditur in sacra Scriptura: scilicet ad destructionem errorum [...]. Proceditur etiam ad instructionem morum [...]. Proceditur tertio ad contemplationem veritatis" [Św. Tomasz z Akwinu, Scripta super libros Sententiarum, Parisi 1929-1947, Prologus, q. 1, a. 5]). Ale według H. de Lubaca nie da się utrzymać, że ta linia pojawia się dopiero w XII wieku. W rzeczywistości występowanie ojców przeciw subiektywnej egzegezie Żydów i heretyków sprawia, że twierdzenie C. Spicqa jest nieprecyzyjne. Por. H. de 
Anielski w dedykacji papieżowi Urbanowi Iv pierwszej części Catena aurea stwierdza, że między innymi jego intencją było obalenie błędów i potwierdzenie prawdy katolickiej ${ }^{102}$. Ten sam cel - według św. Tomasza - miał św. Jan, pisząc Ewangelię przeciw błędom, które dotyczyły boskości Chrystusa ${ }^{103}$. Rzeczywiście, obrona wiary przeciw błędom była jednym $\mathrm{z}$ obowiązków mistrza teologii ${ }^{104}$. A więc odrzucenie błędów jest jednym $\mathrm{z}$ trzech celów sacra doctrina ${ }^{105}$, która kieruje się ku Pismu Świętemu ${ }^{106}$. Jak już wspomnieliśmy, przedstawienie błędne to takie, które jest przeciwne w stosunku do tego, co objawił Duch Święty ${ }^{107}$ i czego naucza Kośció $1^{108}$. Dlatego Doktor Anielski stwierdza także, że studium Pisma Świętego jest konieczne dla zachowania zdrowej nauki przeciw heretykom ${ }^{109}$.

\section{Zakończenie}

W ostatnim stuleciu zauważa się ogromny rozwój studiów egzegetycznych Pisma Świętego i nie można egzegezy współczesnej porównywać z egzegezą średniowieczną. Nie powinno się ich także przeciwstawiać. Niemniej jednak jak się wydaje - egzegeza współczesna mogłaby się zainspirować niektórymi

Lubac, Esegesi medievale, t. 3, s. 19n. Przypuszczalnie można twierdzić, że ten aspekt apologetyczny egzegezy xıI i xıI wieku - podkreślany przez C. Spicqa - ujawnia się w tym okresie z nową siłą dzięki nowemu wysiłkowi budowania teologii jako nauki, w której apologia wiary jest jednym z bardzo ważnych założeń metodologicznych. Por. Św. Tomasz z Akwinu, Summa contra Gentiles, Taurini-Romae 1961, lib. 1, c. 1 i 2.

${ }^{102}$ „Fuit autem mea intentio in hoc opere non solum sensum prosequi litteralem, sed etiam mysticum ponere; interdum etiam errores destruere, necnon confirmare catholicam veritatem" (Św. Tomasz z Akwinu, Catena aurea. Epistola dedicatoria, t. 1, Taurini-Romae 1953, s. 3).

${ }^{103}$ Por. Św. Tomasz z Akwinu, Super Evangelium Ioannis lectura, Prologus, nr 10.

${ }^{104}$ „Ita et doctores Ecclesiae in defensionem fidei debent esse contra errores" (Św. Tomasz z Akwinu, Rigans montes, nr 1212, w: Opuscula Theologica, t. 1, Taurini-Romae 1954). Por. także: A. Patfoort, Tommaso d'Aquino. Introduzione a una teologia, Genova 1988, s. 15n.

${ }^{105}$ Por. Św. Tomasz z Akwinu, Scripta super libros Sententiarum, Prologus, q. 1, a. 5.

${ }^{106}$ Por. M. Arias Reyero, Historia y teología. La interpretación de la Escritura en santo Tomás, S. 504 .

${ }^{107}$ „Ille dicitur aliter exponere sacram Scripturam quam Spiritus sanctus efflagitat qui ad hoc expositionem sacrae Scripturae intorquet quod contrariatur ei quod est per Spiritum sanctum revelatum" (Św. Tomasz z Akwinu, Summa Theologiae, 2-2, q. 11, a. 2, ad 2).

${ }^{108}$ „Quae doctrina sit erronea, hoc ostendit ex tribus. Primo si sit contra doctrinam ecclesiasticam” (Św. Tomasz z Akwinu, Super Primam Epistolam ad Timotheum, c. 6, 1. 1, nr 237).

${ }^{109}$ „Ut custodiant (doctrinam sanam) contra haereticos [...] per studium sacrae Scripturae” (Św. Tomasz z Akwinu, Super Epistolam ad Titum, c. 1, 1. 3, nr 24, w: Super Epistolas Pauli lectura, dz. cyt.). 
elementami egzegezy średniowiecznej, której jednym z najwybitniejszych przedstawicieli był św. Tomasz z Akwinu. Chodzi zwłaszcza o jej charakter teologiczny i patrystyczny. Szersze włączenie tych wymiarów do egzegezy współczesnej jest - jak się wydaje - bardzo potrzebne współczesnemu Kościołowi i mogłoby się przyczynić do jeszcze lepszej percepcji słów Pisma Świętego przez uczniów Chrystusa w Xxi wieku.

\section{Bibliografia}

Allegro C., Il metodo e il pensiero di san Tommaso d'Aquino, Roma 1978.

Arias Reyero M., Historia y teología. La interpretación de la Escritura en santo Tomás, „Salmaticensis” 22 (1975), s. 499-526.

Arias Reyero M., Thomas von Aquin als Exeget, Einsiedeln 1971.

Biffi I., La teologia e un teologo: San Tommaso d'Aquino, Casale Monferrato 1984. Chenu M.-D., Introduzione allo studio di san Tommaso d'Aquino, Firenze 1965.

Chenu M.-D., La teologia come scienza nel XIII secolo, Milano 1985.

Cirillo A., Cristo Rivelatore del Padre nel Vangelo di s. Giovanni secondo il Commento di s. Tommaso d'Aquino, Roma 1988.

Correia Margarido J., A analogia da Fé na exegese de S. Tomás, „Theologica” 13 (1978), s. 328-350.

Ferraro G., Lo Spirito Santo nel Commento di san Tommaso d'Aquino ai capitoli XIV-XVI del Quarto Vangelo, w: San Tommaso d'Aquino nel settimo centenario, a cura di B. D’Amore, t. 4, Napoli 1976, s. 79-91.

Ferraro G., Il tema dello Spirito Santo nel Commento di San Tommaso d'Aquino agli Ebrei (annotazioni di dottrina e di esegesi tomista), „Studi Tomistici” 13 (1981), s. $172-188$.

Gardeil A., La réforme de la théologie catholique. Les procédés exégètiques de Saint Thomas, „Revue Thomiste” 15 (1903), s. 452-456.

Geenen G., Le fonti patristiche come „autorità" nella teologia di s. Tommaso, „Sacra Doctrina" 20 (1975), s. 7-67.

Geenen G., Saint Thomas et les Pères, w: Dictionaire de théologie catholique, sous la direction A. Vacant, E. Mangenot, É. Amann, t. 15, Paris 1946, kol. 738-761. Lottin O., Comment interpréter et utiliser saint Thomas d'Aquin, „Ephemerides Theologicae Lovanienses" 36 (1960), s. 57-76.

Lubac H. de, Esegesi medievale, t. 4, Roma 1962-1972.

Patfoort A., Tommaso d'Aquino. Introduzione a una teologia, Genova 1988. 
Pieper J., Guide to Thomas Aquinas, Notre Dame (Indiana) 1987.

Siedl S. H., Thomas von Aquin und die moderne Exegese, „Zeitschrift für Katholische Theologie" 93 (1971), s. 29-44.

Spicq C., Exégèse médiévale, w: Dictionnaire de la Bible. Supplement, t. 4, 1949.

Spicq C., Saint Thomas d'Aquin exégète, w: Dictionnaire de la théologie catholique, sous la direction A. Vacant, E. Mangenot, É. Amann, t. 15, Paris 1946, kol. 694-738.

Vansteenkiste C. M. J., Il metodo di san Tommaso, w: Le ragioni del tomismo. Dopo il centenario dellenciclica „Aeterni Patris”, a cura di A. Livi, C. Fabro, F. Ocariz, C. M. J. Vansteenkiste, Milano 1979, s. 161-196.

Weisheipl J. A., Tomasz z Akwinu. Życie, myśl i dzieło, tłum. C. Wesołowski, Poznań 1985.

Św. Augustyn, De Genesi ad litteram (Nuova Biblioteca Agostiniana 9/2) Roma 1989; PL 34, 245-466.

Św. Tomasz z Akwinu, Catena aurea, Taurini-Romae 1953.

Św. Tomasz z Akwinu, Commento al Vangelo di San Giovanni, t. 1, Roma 1990.

Św. Tomasz z Akwinu, Contra errores Graecorum, w: Opuscula Theologica, t. 1, Taurini-Romae 1954.

Św. Tomasz z Akwinu, Expositio in Librum Sancti Job, Parisiis 1876.

Św. Tomasz z Akwinu, Expositio super Isaiam, Ed. Typographia S.C. de Propaganda Fide, Romae 1880.

Św. Tomasz z Akwinu, In Dionysii De divinis nominibus, Taurini-Romae 1950.

Św. Tomasz z Akwinu, Quaestio disputata De Potentia, w: Quaestiones disputatae, t. 2, Taurini-Romae 1965, s. 7-276.

Św. Tomasz z Akwinu, Quaestio disputata De Spiritualibus Creaturis, w: Quaestiones disputatae, t. 2, Taurini-Romae 1954, s. 367-415.

Św. Tomasz z Akwinu, Quaestiones Quodlibetales, Romae 1949.

Św. Tomasz z Akwinu, Rigans montes, w: Opuscula Theologica, t. 1, Taurini-Romae 1954.

Św. Tomasz z Akwinu, Scripta super libros Sententiarum, Parisi 1929-1947.

Św. Tomasz z Akwinu, Summa contra Gentiles, Taurini-Romae 1961.

Św. Tomasz z Akwinu, Summa Theologiae. La Somma Teologica, traduzione e commento a cura dei Domenicani italiani. Testo latino delledizione leonina, vol. 1-34, Città di Castello 1950-1975.

Św. Tomasz z Akwinu, Super Epistolam ad Ephesios lectura, w: Super Epistolas Pauli lectura, Taurini-Romae 1953. 
Św. Tomasz z Akwinu, Super Epistolam ad Galatas lectura, w: Super Epistolas Pauli lectura, Taurini-Romae 1953.

Św. Tomasz z Akwinu, Super Epistolam ad Romanos lectura, w: Super Epistolas Pauli lectura, Taurini-Romae 1953.

Św. Tomasz z Akwinu, Super Epistolam ad Titum, w: Super Epistolas Pauli lectura, Taurini-Romae 1953.

Św. Tomasz z Akwinu, Super Evangelium Ioannis lectura, Taurini-Romae 1952. Św. Tomasz z Akwinu, Super Evangelium Matthaei lectura, w: Tommaso D’Aqcuino,

Commento al Vangelo Secondo Matteo, capitoli 1-14, intorduzione e traduzione R. Coggi, Bologna 2018.

Św. Tomasz z Akwinu, Super Primam Epistolam ad Corinthios lectura, w: Super Epistolas Pauli lectura, Taurini-Romae 1953.

Św. Tomasz z Akwinu, Super Primam Epistolam ad Timotheum, w: Super Epistolas Pauli lectura, Taurini-Romae 1953.

\section{Streszczenie}

Święty Tomasz z Akwinu był nie tylko znakomitym filozofem i teologiem, ale także niestrudzonym egzegetą Pisma Świętego. Spod jego pióra wyszły komentarze zarówno do ksiąg Starego, jak i Nowego Testamentu. Egzegeza św. Tomasza z Akwinu odznacza się kilkoma cechami. Jest to egzegeza oparta na dwóch fundamentalnych regułach: analogii wiary katolickiej i analogii wiary biblijnej. Ponadto posiada także charakterystyczny dla całej egzegezy średniowiecznej rys scholastyczny, patrystyczny i teologiczny.

\section{Słowa kluczowe}

św. Tomasz z Akwinu, egzegeza Pisma Świętego, analogia wiary katolickiej, analogia wiary biblijnej, egzegeza scholastyczna, egzegeza patrystyczna, egzegeza teologiczna

\section{Summary}

\section{The Unique Characteristics of St. Thomas from Aquinas' Exegesis of the Holy Bible}

St. Thomas of Aquinas was not only a formidable philosopher and theologist, but also he was a tireless exegete of the Holy Scripture. He wrote comments on the 
books of both the Old and New Testament. His exegesis has several traits. It is constructed around two fundamental rules: the analogy of Catholic faith and the analogy of Biblical faith. Furthermore it contains a typical to the Medieval exegesis - scholastic, patristic and theological lineament.

\section{Keywords}

St. Thomas of Aquinas, Holy Bible exegesis, analogy of Catholic faith, analogy of Biblical faith, scholastic exegesis, patristic exegesis, theological exegesis 